\title{
A processão do absoluto: notas sobre Merleau-Ponty e Schelling ${ }^{1}$
}

\section{[The procession of the absolute: remarks on Merleau-Ponty and Schelling]}

\author{
Rafael Zambonelli Nogueira \\ Mestrando em filosofia pela USP e bolsista Fapesp
}

Resumo: O presente artigo busca analisar as relações entre Merleau-Ponty e Schelling a partir de um ângulo diferente dos (poucos) trabalhos dedicados a essa questão, os quais costumam se limitar à retomada por parte de Merleau-Ponty da primeira filosofia da natureza de Schelling. Analisaremos tais relações tomando como fio condutor a ideia schellinguiana de Absoluto e como ela é retomada por Merleau-Ponty na medida em que implica uma concepção não-separada do Absoluto e, ipso facto, sua temporalização e historicização - o que não significa, é claro, uma recaída no relativismo, mas uma elaboração ontológica (e "dialética", se se quiser, mas em um sentido a ser precisado no texto) que supera as dicotomias clássicas entre universalidade e singularidade, infinitude e finitude, temporalidade e eternidade etc., articulando-as dinamicamente no interior do Absoluto como unidade que exige a diferenciação e a multiplicidade.

Palavras-chave: Absoluto; Dialética; História; Temporalidade; Infinitude; Fenomenologia

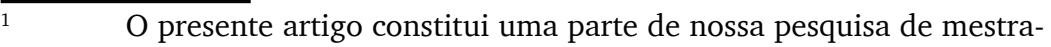
do em andamento com apoio da FAPESP. 
Abstract: The present article seeks to analyze the relations between Merleau-Ponty and Schelling from a different angle from the (not so many) works on this question, which are usually limited to Merleau -Ponty's retaking of Schelling's first philosophy of nature. We will analyze such relations by taking as a guiding thread Schelling's idea of the Absolute and how it is taken up by Merleau-Ponty insofar as it implies an unseparated conception of the Absolute and, ipso facto, its temporalization and historicization - which does not mean, of course, a relapse into relativism, but an ontological (and "dialectical", but in a sense to be precised in the text) elaboration that overcomes the classical dichotomies between universality and singularity, infinity and finitude, temporality and eternity, etc., articulating them dynamically within the Absolute as a unity that requires differentiation and multiplicity.

Keywords: Absolute; Dialectics; History; Temporality; Infinity; Phenomenology

"Homme, si tout est faux hormis la vérité Voici que tu la sens en toi vivre, - que faire?"

(Paul Claudel, Vers d'exil)

Merleau-Ponty, como se sabe, possuía pouca familiaridade com a obra de Schelling: seu único contato textual com a obra do filósofo alemão se deu através da coletânea de textos (alguns completos, outros incompletos) organizada por Jankélévitch em 1947 sob o título de Essais, além de um contato indireto por meio da leitura de livros de Jaspers, Löwith, entre outros. Essa falta de familiaridade parece se refletir no fato de que o fenomenólogo só comenta de modo mais extenso as ideias de Schelling em uma parte de seu curso de 1956-1957 intitulado Le concept de nature, além de poucas referências pontuais em textos posteriores. No entanto, não seria exagerado dizer que esse contato breve e fragmentário marcou profundamente a obra de Merleau-Ponty, o que se revela, por exemplo, em sua apropriação de conceitos schellinguianos tais como "princípio bárbaro", "abismo" e "imemorial", conceitos que aparecerão em momentos decisivos da elaboração mais acabada — e, infe- 
lizmente, interrompida pela morte prematura do filósofo — de seu projeto ontológico em Le visible et l'invisible.

Para o historiador da filosofia, medir esse impacto e pensar a convergência entre os dois autores se apresenta como uma tarefa ingrata, já que Merleau-Ponty comenta a obra de Schelling sem levar em conta as periodizações tradicionalmente estabelecidas pelos comentadores. Mas essa insuficiência é reconhecida pelo próprio Merleau-Ponty — e, a bem da verdade, qualificá-la como insuficiência seria um equívoco, pois consistiria em perder de vista tanto a natureza de sua apropriação das ideias schellinguianas quanto a originalidade dessa leitura. Melhor seria, segundo a bela expressão de Francesco Moiso, falar em uma "desenvoltura teórica" . Com efeito, em uma nota inédita de preparação do curso supracitado, Merleau-Ponty escreve: "Sem interpretação da filosofia de Schelling: ela variou / ela não é composta, mas sempre recomeçada. / Por razão de princípio: é uma experiência, não uma Grundsatzphilosophie. / Buscaremos descrever o elo intelectual dessa experiência" (apud Larison, 2016, p. 72). Assim, é precisamente como uma experiência do pensamento que Merleau-Ponty busca ler a obra de Schelling - o que o dispensa de partida da necessidade de uma leitura "sistemática" tal como faria um "intérprete institucional", como diz Moiso - e é nessa "desenvoltura" que reside todo o interesse de tal comentário.

A partir de uma confrontação entre Merleau-Ponty e Schelling, buscaremos mostrar no presente texto de que maneira Merleau-Ponty, reconstituindo essa experiência do pensamento, retoma a ideia schellinguiana de Absoluto, encontrando nela tanto algo que vai ao encontro de sua própria filosofia quanto algo que traz elementos novos que serão incorporados a sua reflexão. Para isso, voltaremos nossa atenção sobretudo ao

$2 \quad$ Cf. Moiso, 1998, p. 85: "A este propósito, Merleau-Ponty restitui uma leitura muito aguda do texto schellinguiano, a despeito de certos saltos cronológicos que, não respeitando a ordem das obras, misturam alguns conceitos que um especialista nunca misturaria. Todavia, essa 'desenvoltura teórica' concede a Merleau-Ponty o que poderíamos chamar de audácia dos autores não institucionais, os quais por vezes veem o que o intérprete institucional não vê ou não quer ver, na medida em que, provavelmente, isso iria corroer os fundamentos de um sistema interpretativo penosamente erigido". 
período da assim chamada "filosofia da identidade", na medida em que aí o sistema aparece pela primeira vez como sistema do absoluto. Mais importante, contudo, que a própria exposição da filosofia da identidade é acompanhar a tensão que lhe é característica e que abrirá caminho para a Spätphilosophie — da qual não trataremos aqui. Da mesma forma, não nos restringiremos ao comentário que Merleau-Ponty faz da filosofia schellinguiana no curso sobre o conceito de natureza, mas tentaremos mostrar uma incidência mais geral do pensamento de Schelling na obra do fenomenólogo.

Segundo Merleau-Ponty, o grande mérito de Schelling foi ter chegado, a partir de sua filosofia da natureza, a uma concepção do Absoluto enquanto não-separado. No entanto, é difícil compreender essa asserção se pensarmos no caráter fortemente eternitário do sistema da identidade, caráter que resulta em uma desvalorização da realidade finita e fenomenal como puro nada. Partindo da Darstellung de 1801 — primeira exposição do sistema em sua absolutez — deveremos, pois, tentar compreender tal concepção de Absoluto e em que medida ele pode ser pensado como não-separado, o que revelará o sentido da tensão de que falamos acima.

Em sua sistematicidade, o Absoluto se expõe enquanto tal, na medida em que o ponto de vista da filosofia é o ponto de vista da razão e esta, por sua vez, é o conhecimento das coisas tal como elas são em si, ou seja, na própria razão. Nessa auto -exposição do Absoluto, diz Schelling, ele se manifesta como identidade absoluta, isto é, como absoluta unidade e identidade consigo mesmo, cuja fórmula mais geral pode ser expressa pela proposição $\mathrm{A}=\mathrm{A}$. Ora, se a razão é o próprio Absoluto, não pode haver nada fora dela, de modo que tudo deve ser nela. Assim, a lei da identidade $(\mathrm{A}=\mathrm{A})$ vale para todo ser, na medida em que ele é considerado tal como é em si, no Absoluto. Essa proposição, $\mathrm{A}=\mathrm{A}$, é o único conhecimento incondicionado, uma vez que é o único a exprimir a essência da razão - e a 
identidade absoluta, na medida em que é imediatamente posta com tal proposição, é absolutamente e seu ser é uma verdade eterna visto que a verdade de seu ser é idêntica à verdade da proposição $\mathrm{A}=\mathrm{A}$. Da mesma forma, se não pode haver nada fora da identidade absoluta, isso significa que ela é absolutamente infinita, pois nada pode limitá-la do exterior, de modo que tudo o que é deve ser necessariamente a própria identidade absoluta. Por conseguinte, tudo o que é, é em si um e, dada a eternidade da identidade absoluta, não pode começar nem perecer, mas deve ser absolutamente eterno segundo o ser em si. Desde então, não é possível falar em uma finitude em si, pois o que é, considerado em si, só pode ser a própria identidade absoluta e, portanto, absolutamente infinito. Por tudo isso, a identidade absoluta só pode ser pensada como absoluta totalidade - ou "universo" —, na medida em que ela é tudo o que é.

É preciso, contudo, compreender corretamente a lei da identidade: a proposição $\mathrm{A}=\mathrm{A}$ não põe o ser de $\mathrm{A}$ em geral nem de A enquanto sujeito ou predicado. Ao contrário, "o único ser que é posto por essa proposição é o da própria identidade, a qual é, por isso, posta de maneira totalmente independente do A enquanto sujeito e do A enquanto predicado" (Schelling, 1859a, SW IV, p. 117) ${ }^{3}$. A proposição A = A é a forma da identidade absoluta, forma que é posta imediata e simultaneamente por seu ser: a identidade absoluta só é sob essa forma, que é a forma da identidade da identidade. Mas, se a identidade absoluta é posta nessa proposição de maneira independente de A enquanto sujeito e de A enquanto predicado, isso significa que o que pertence simplesmente à forma do ser da identidade absoluta não é posto em si, ou seja, não pertence a sua essência, uma vez que nenhuma oposição é em si possível entre A enquanto sujeito e A enquanto predicado. Em outras palavras, "na medida em que ambos são sujeito e predicado, eles pertencem não à essência, mas somente ao ser da identidade absoluta, mas, na medida em que eles pertencem à essência da própria identidade absoluta [ou são a própria identidade absoluta], eles não podem ser pensados como diferentes" (Ibid., p. 121). À forma

3 As citações de Schelling remeterão às Sämtliche Werke de forma abreviada como SW, indicando em seguida o volume e a página. 
de seu ser, dirá Schelling, pertence imediatamente o conhecimento originário da identidade absoluta - conhecimento que é posto imediatamente com a proposição $\mathrm{A}=\mathrm{A}-$, de modo que "portanto, o conhecimento originário da identidade absoluta é ao mesmo tempo seu ser segundo a forma e, inversamente, cada ser, segundo a forma, é também um conhecer - (não um ser conhecido [Erkanntwerden]) — da identidade absoluta" (Ibid., p. 122). Se a forma do ser da identidade absoluta é um conhecer, ou seja, se a identidade absoluta só é sob a forma do conhecimento infinito de sua identidade consigo mesma, então a identidade absoluta só conhece a si mesma infinitamente na medida em que ela se põe infinitamente enquanto sujeito e objeto - e aqui é preciso levar em conta o fato de que é a mesma identidade (A) que, segundo a forma, é posta enquanto sujeito e enquanto objeto e, portanto, como identidade da identidade (A = A). Mas isso implicará, por outro lado, que do ponto de vista da forma é necessário conceber uma diferença no interior da identidade, embora tal diferença não possa ser concebida como qualitativa (pois é a mesma identidade que é posta enquanto sujeito e objeto), mas somente como diferença quantitativa, na medida em que se põe uma predominância da subjetividade ou da objetividade pela qual $\mathrm{A}=\mathrm{A}$ se metamorfoseia em $\mathrm{A}=\mathrm{B}$, sendo B o signo da objetividade ${ }^{4}$. Daí que Schelling diga que a forma da sujeito-objetividade só pode ser em ato ou posta efetivamente se uma diferença quantitativa entre sujeito e objeto é posta, ou seja, se subjetividade e objetividade são postas enquanto tais, pois, sem isso, não haveria nenhuma diferenciação possível e, portanto, a forma seria destruída enquanto forma.

Ora, se a identidade absoluta é idêntica à indiferença absoluta entre o subjetivo e o objetivo, não pode haver nenhuma diferença quantitativa em seu interior. Em outras palavras, a diferença só pode existir na forma, jamais na essência, o que

$4 \quad$ Cf. Ibid., p. 123: "uma vez que nenhuma diferenciação entre ambos é possível a respeito do próprio ser (pois ela [sc. a identidade] é enquanto sujeito e objeto de maneira igualmente incondicionada e, portanto, também a mesma segundo a essência), resta apenas uma diferença quantitativa, isto é, uma diferença tal que só tem lugar a respeito da grandeza do ser, a saber, de tal modo que é um Único e mesmo idêntico que é posto, mas com uma predominância da subjetividade [do conhecer] ou da objetividade [do ser]". 
significa dizer que, não obstante não haja nada fora da identidade absoluta, a diferença quantitativa só é possível fora dela - e se, como dissemos, a identidade absoluta é absoluta totalidade, então a diferença quantitativa só é possível fora da absoluta totalidade. Com isso, chegamos, pois, à definição schellinguiana do ser singular, que não é outra coisa que o que é fora da totalidade. Mas esse estatuto paradoxal do ser singular no interior do sistema da identidade deve ser bem compreendido: com efeito, "não há ser singular ou coisa singular em si" (Ibid., p. 125), de modo que a diferença quantitativa só pode ser pensada em relação ao ser singular, mas não em si ou em relação à absoluta totalidade. A diferença quantitativa é posta unicamente no fenômeno, e não em si, na medida em que a identidade absoluta não é afetada pela oposição entre subjetividade e objetividade. Assim, "a diferença quantitativa, em geral, só é posta pelo ato de separação [Absonderungsakt] e a respeito deste" (Ibid., p. $127 n)^{5}$, ato de separação que é realizado precisamente pela atividade da reflexão, que separa arbitrariamente o singular da totalidade - em outras palavras, a diferença é posta idealiter pela reflexão, ao passo que as coisas que aparecem para nós como diferentes são realiter idênticas. Desse modo, conclui Schelling, "se a diferença quantitativa tem lugar efetivamente a respeito da coisa singular, então, a identidade absoluta, na medida em que ela é, deve ser representada enquanto indiferença quantitativa da subjetividade e da objetividade" (Ibid., p. 126). Se a forma da sujeito-objetividade só é efetivamente na medida em que uma diferença quantitativa é posta fora da totalidade, então, correlata e simetricamente, a totalidade ou a identidade absoluta só é sob a forma da indiferença quantitativa do subjetivo e do objetivo. Isso vai implicar, segundo Schelling, a identidade entre infinito e finito, uma vez que, com o singular,

5 Se o sistema da identidade não pode admitir uma passagem do infinito ao finito, o problema que o atravessa consiste justamente em pensar a origem dessa Absonderung, problema que, segundo Schelling, não pode ainda receber uma resposta no âmbito da Darstellung. Sabe-se, porém, que uma primeira tentativa de resposta mais acabada aparecerá três anos mais tarde, em Philosophie und Religion, a partir da ideia de queda [Abfall]. Mas já em 1802, no diálogo Bruno, Schelling aborda com mais detalhes o problema da relação entre o infinito e o finito por meio da elaboração, de inspiração platônica, do conceito de ideia. 
é imediatamente posto também o todo: "portanto, o absoluto só é posto enquanto absoluto se ele for posto no singular com uma diferença quantitativa, mas com indiferença no todo. Mas essa diferença no singular e essa indiferença no todo são precisamente a totalidade" (Ibid., p. 127n).

Como compreender essa identidade entre infinito e finito? Com efeito, se o ser singular, enquanto tal, não pode ter o fundamento de sua existência [Daseyn] em si mesmo, então ele deve ser determinado por um outro ser singular e assim ao infito, de sorte que o ser singular é necessariamente determinado, o que equivale a dizer que ele é limitado e, portanto, finito. Assim, na medida em que a diferença quantitativa entre subjetividade e objetividade é o fundamento de todo ser singular, ela deve ser considerada ipso facto como fundamento de toda finitude, fundamento que encontra em $\mathrm{A}=\mathrm{B}$ sua expressão universal. Inversamente, a infinitude não poderá ser caracterizada de outro modo senão como a indiferença quantitativa. E, como vimos, há uma simultaneidade entre a posição do singular e a da totalidade, simultaneidade que garante a ausência de passagem do infinito ao finito: não há um ponto inicial em que a identidade absoluta tenha passado em uma coisa singular, justamente porque o que é originário é a totalidade, e não o singular - e pensar uma passagem implicaria conceber o infinito e o finito existindo originariamente lado a lado, o que é absurdo. Em outras palavras, o finito não pode ser por si mesmo, ele só é enquanto está contido na totalidade, de modo que a série em que um singular é determinado por outro singular deve necessariamente remontar ao infinito.

Desde então, o ser singular e finito é, enquanto tal, "uma forma determinada do ser da identidade absoluta, mas não seu próprio ser, o qual só é na totalidade" (Ibid., p. 131). Isso é claro pelo fato de que a forma do ser da identidade absoluta consiste na subjetividade e na objetividade em geral e, portanto, uma diferença quantitativa determinada entre os dois deve ser concebida como uma forma determinada do ser da identidade absoluta. Ora, se é assim, todo ser singular é uma expressão da identidade absoluta sob uma forma determinada do ser e - se a essência da identidade absoluta é indivisível na medida em 
que ela é independente da subjetividade e da objetividade e, por conseguinte, de toda diferença quantitativa -, "a identidade absoluta é, no singular, sob a mesma forma que ela é no todo $e$, inversamente, ela não é no todo sob uma forma diferente da forma sob a qual ela é no singular" (Ibid., p. 132). É em virtude dessa dinâmica expressiva que Schelling dirá que o ser singular é infinito em seu gênero (ou em sua potência) e uma totalidade em relação a si mesmo. Ele é infinito porque, embora não seja absolutamente infinito visto que é determinado, o ser singular é infinito a respeito de sua potência, "pois ele exprime o ser da identidade absoluta para a sua potência sob a mesma forma que o infinito", potência que é, por sua vez, determinada pela diferença quantitativa. Mas, ao mesmo tempo e consequentemente, ele é uma totalidade, pois "cada $\mathrm{A}=\mathrm{B}$ é, em relação a si mesmo ou considerado em si mesmo, um $\mathrm{A}=\mathrm{A}$, portanto, algo absolutamente igual a si mesmo", o que é exigido pelo fato de que "tudo o que é só é na medida em que exprime a identidade absoluta sob uma forma determinada de seu ser" (Ibid., p. 133) ${ }^{6}$. Em outras palavras, a predominância da subjetividade ou da objetividade em uma potência determinada só aparece como desequilíbrio ou identidade relativa $(A=B)$ em relação ao todo, não em relação a tal potência, em que o $\mathrm{A}=\mathrm{B}$, considerado em si mesmo, é o $\mathrm{A}=\mathrm{A}$ dessa potência. Essa totalidade será, por sua vez, chamada de totalidade relativa, na medida em que é a exposição da totalidade absoluta pelo singular e, sendo absoluta em relação ao singular, é relativa em relação à totalidade absoluta, pois esta só pode existir sob a forma de todas as potências, as quais são, ipso facto, absolutamente simultâneas entre si, ou seja, absolutamente eternas e sem nenhuma relação com o tempo.

$6 \quad$ Sobre o uso do conceito de potência - quase onipresente na filosofia de Schelling — na Darstellung, cf. Ibid. p. 134: "Cada potência determinada designa uma diferença quantitativa determinada da subjetividade e da objetividade, a qual tem lugar em relação ao todo ou à totalidade absoluta, mas não em relação a essa potência, de modo que, por exemplo, um expoente negativo de A designa uma predominância da objetividade a respeito do todo (portanto, a respeito tanto de A quanto de B), ao passo que, justamente porque essa predominância é comum a ambos a respeito da própria potência na qual ela tem lugar, um perfeito equilíbrio entre os dois fatores é possível e, portanto, o $\mathrm{A}=\mathrm{B}$ é um $\mathrm{A}=\mathrm{A} "$. 
Por fim, a forma do ser da identidade absoluta, na medida em que A e B são postos em todas as potências como identicamente reais, pode ser pensada universalmente segundo a imagem de uma linha "em que, em cada direção, o mesmo idêntico, mas em direções opostas com A ou B predominante, é posto, mas com o próprio $\mathrm{A}=\mathrm{A}$ recaindo no ponto de equilíbrio" (Ibid., p. 137), em que o sinal + designa a predominância:

$$
\underline{\mathrm{A}^{+}=\mathrm{B}} \quad \mathrm{A}=\mathrm{B}^{+}
$$$$
\mathrm{A}=\mathrm{A}
$$

E Schelling precisa que essa linha pode ser estendida ao infinito e que ela é absolutamente idêntica em cada uma de suas partes, isto é, que em toda parte se encontrará a mesma estrutura ternária, porquanto através de toda a linha é sempre o mesmo Idêntico que é posto infinitamente, de sorte que essa linha, como fórmula fundamental da construção do sistema, é a forma do ser da identidade absoluta tanto no singular quanto no todo.

Com essa reconstituição de parte da Darstellung de 1801, podemos compreender agora a tensão que visávamos, uma vez que ali ela aparece em sua forma mais dramática: trata-se daquilo que Schelling chamará de vida dupla do finito, isto é, uma vida nula em si mesmo e uma vida absoluta no todo. Tal vida dupla aparece nesse texto, como nota Judith Schlanger (cf. Schlanger, 1966, pp. 119 et seq.), como duas respostas diferentes ao problema da diferença, isto é, do nível em que se situa a diferença entre subjetividade e objetividade e da relação entre os seres singulares e a identidade-totalidade absoluta. Por um lado, a diferença é ligada à mera idealidade, ou seja, à atividade separadora da reflexão que instaura arbitrariamente um desequilíbrio quantitativo que transforma o $\mathrm{A}=\mathrm{A}$ em um $\mathrm{A}=$ B. Desse ponto de vista, a diferença e, por conseguinte, a finitude não possuem nenhuma realidade, elas são um nada, consistindo em meras ilusões ligadas à ordem fenomênica a partir da ruptura reflexiva que separa o singular do todo. Assim, se perguntarmos o que é o singular em relação à totalidade abso- 
luta, a única resposta possível parece ser a seguinte: "Porém, em relação a esta, enquanto singular, ele não é absolutamente; pois, considerado do ponto de vista da totalidade absoluta, somente ela é e fora dela nada é" (Schelling, 1859a, SW IV, p. 133). Mas, por outro lado, Schelling já anuncia uma outra compreensão do finito que será fundamental no desenrolar de sua obra e que lhe confere um estatuto de certa forma mais elevado. Com efeito, se o fundamento da finitude é a diferença quantitativa e se a identidade absoluta só pode ser efetivamente, enquanto indiferença quantitativa, se uma diferença é posta entre subjetividade e objetividade, então é preciso dizer que, por sua forma, a identidade absoluta implica necessariamente a finitude, pois sua atualidade depende dessa diferença que produz os seres singulares, de sorte que o Absoluto e o finito são postos simultaneamente ${ }^{7}$. Há, assim, uma dialética implícita na noção de singularidade enquanto forma determinada e expressão do ser da identidade absoluta. O absoluto só pode se revelar através

7 Com efeito, no Bruno Schelling dará uma formulação mais adequada do Absoluto enquanto unidade da identidade e da diferença, ou seja, da identidade $\mathrm{A}=\mathrm{A}$ e da diferença $\mathrm{A}=\mathrm{B}$. Cf. Schelling, 1973, p. 249; SW IV, p. 236: "como fazemos da unidade de todas as oposições o primeiro, mas a própria unidade, juntamente com aquilo que denominamos oposição, forma, por sua vez, uma oposição, e aliás a suprema, nós, para fazer daquela a unidade suprema, temos de pensar também essa oposição, juntamente com a unidade que se contrapõe a ela, como compreendida naquela, e determinar aquela unidade como unidade em que a unidade e a oposição, o igual a si mesmo e o desigual, são um".

Mais tarde, esse caráter orgânico do sistema, implicado pela identidade da identidade e da diferença, enquanto totalidade racional, aparecerá de modo ainda mais claro. Cf. e.g. Schelling, 1860b, SW VII, p. 425: "Se pusermos A = A como o estado do ser abismado [verschlungenen] em si, então, nesse $\mathrm{A}=$ A, já temos três coisas a notar, a) A enquanto objeto, b) A enquanto sujeito, c) a identidade de ambos; mas tudo isso é realmente [reell] indistinguível. Ora, uma diferença dos princípios deve ser posta: portanto, uma vez que A enquanto sujeito e A enquanto objeto são distinguíveis, então, o $\mathrm{A}=\mathrm{A}$ se metamorfoseia em $\mathrm{A}=\mathrm{B}$; mas, uma vez que apesar disso a unidade do ser permanece, então, a expressão da diferença, em vez de $\mathrm{A} / \mathrm{A}=\mathrm{A}$, é $\mathrm{A} / \mathrm{A}=\mathrm{B}$, i.e., um e dois; $\mathrm{A}=\mathrm{B}$ é a divisão-em-dois* [Entzweiung], $\mathrm{A}$ a unidade e $\mathrm{o}$ todo tomado conjuntamente é o ser originário vivo, atual; A encontrando em $\mathrm{A}=\mathrm{B}$ um objeto, um espelho. Portanto, em si, o ser originário é sempre uma unidade - unidade da oposição e da divisão em dois".

*: seguimos aqui Jean-François Courtine ao traduzir Entzweiung por "divisão -em-dois", e não por "cisão". 
da diferença, mas em cada uma delas ele está inteiro, pois sua essência é indivisível. Desde então, há uma singularização do Absoluto que não suprime sua identidade e unidade consigo mesmo, mas que é ao mesmo tempo um retorno à universalidade. O singular é exposição, expressão — ou, segundo outra formulação possível, reflexo, imagem e revelação — do Absoluto, na medida em que "no Absoluto todas as coisas particulares são verdadeiramente separadas e verdadeiramente uma somente porque cada uma é, por si, o universo, cada uma é o todo absoluto" (Schelling, 2010, p. 52; SW V, p. 389) ${ }^{8}$. Desse modo, a tensão entre essas duas respostas deverá permanecer como uma tensão de pontos de vista, expressa pela ambiguidade da própria palavra einzeln, que pode significar tanto "singular" quanto "isolado". Em outras palavras, nessa "vida dupla" do finito Schelling se coloca na esteira de Herder ao insistir nesses dois modos de olhar as coisas singulares, a saber, como separadas ou como partes de um todo - e todo o problema da filosofia consiste justamente em separar o que é singular em vez de considerá-lo como parte do todo, isto é, na identidade e simultaneidade entre singular e universal, finito e infinito, temporal e eterno. Esse segundo modo de olhar - que é o ponto de vista do Absoluto - , suprime a cisão entre o mundo fenomênico e as coisas em si: o filósofo "reconhece que não há dois mundos, mas apenas Um mundo verdadeiro, o qual não está fora ou aci-

\footnotetext{
$8 \quad$ Cabe aqui um breve esclarecimento. Há certa oscilação terminológica nos textos entre "singular" [einzeln] e "particular" [besondere], pois, ao contrário de autores mais ou menos contemporâneos como Kant e Hegel, Schelling não estabelece uma distinção rígida entre os dois conceitos, o que lhe permite um uso mais "fluido" deles. Em ambos os casos, Schelling se aproveita da etimologia e da ambiguidade dos termos: einzeln, além de remeter de maneira mais clara ao problema da individualidade, mantém como explicamos a seguir no próprio texto - uma ambiguidade na medida em que pode significar tanto "singular" quanto "isolado"; besondere, por sua vez, segue a mesma lógica, podendo significar "particular" ou "separado" (do verbo sondern, donde inclusive o substantivo frequentemente empregado por Schelling: Absonderung). Assim, tanto einzeln quanto besondere dão conta de pensar essa "vida dupla" do finito. Embora seja uma questão delicada — e que não poderia ser resolvida em uma nota de rodapé — saber se há efetivamente uma distinção entre "singular" e "particular" na filosofia de Schelling, parece-nos que há, em geral, uma tendência à sinonímia, como no caso dessa citação da Filosofia da Arte.
} 
ma do mundo que aparece, mas nele mesmo" (Schelling, 1860c, SW VI, p. 274) 9 .

Daí que o sistema da identidade seja o sistema em que o Absoluto se manifesta como pura identidade, mas não como identidade formal e vazia do $\mathrm{A}=\mathrm{A}$, mas como "a identidade racional, ou seja, igualmente aquela que inclui em si o "princípio de razão' - Satz vom Grunde - , a posição fecunda do fundamento que desenvolve reflexivamente em consequências o seu princípio", de modo que "é legítimo dizer do sistema da identidade que ele é de partida e de ponta a ponta fenomenológico, uma vez que ele evidencia a processão do absoluto, sua figuração" (Courtine, 1990a, pp. 116, 120). O Absoluto, ou Deus, aparece, pois, como infinita afirmação de si mesmo e o A = A também como identidade absoluta do afirmante e do afirmado, de modo que Deus é a posição infinita de infinitas posições de si mesmo. Assim, "as coisas consideradas em sua verdade, i.e., em sua essência, são apenas irradiações ou, para falar segundo uma imagem leibniziana, fulgurações da afirmação infinita, que, assim como só podem ser nela e com ela, também são igualmente em si mesmas" (Schelling, 1860a, SW VII, p. 162). E essa fulguração é, como vimos, também uma figuração pela qual o Absoluto reflete a si mesmo, manifesta-se e reconhece sua identidade refletida na diferença, de modo que a identidade deve ser pensada como processo de identificação por meio da formação-em-um [Ineinsbildung] de essência e forma: "a essência se manifesta [scheinet] na forma, mas, em contrapartida, também a forma se manifesta na essência" (Schelling, 1859b, SW IV, p. 417). Esse processo não é outra coisa que o fato de que a totalidade orgânica do sistema é escandida por potências determinadas, ou seja, que o Absoluto possui diferentes momentos, sendo o primeiro o momento "figurativo" da informação (Einbildung) da essência na forma: "a essência (Wesen) toma forma, assume uma figura que lhe é própria; disso, deve-se entender que a essência não se abriga por detrás da forma nem se reserva nela, 9 Cf. também Schelling, 1860a, SW VII, 164-5: "Essa imagem que não é nada em si e para si [...] torna-se, contudo, reflexo nesse não-ser-nada para si tanto da infinitude (pois, nela, as posições são apenas ligadas, mas não unidas) quanto da unidade; e, assim como ambas são unidas de maneira absoluta em Deus e na idea, também o são de maneira finita na coisa". 
mas passa inteiramente nesta, uma vez que é somente através da forma que ela pode revelar-se"; primeira potência que, por sua vez, é sucedida por uma segunda, a reflexão ou informação da forma na essência (Zurückbildung ou Wiedereinbildung), pela qual a diferenciação é retomada pela essência absoluta. Mas "in-formação e reapropriação não sucedem uma à outra, mas se interpenetram de partida até a coincidência na unidade da absoluta uni-formação (Ineinsbildung), pela qual a essência integralmente figurada na forma brilha nela com toda sua 'parência', ao passo que, em contrapartida, a forma ilumina a essência" (Courtine, 1990a, pp. 125-6).

Torna-se, assim, compreensível que Merleau-Ponty veja em Schelling a concepção de um Absoluto não-separado. É que a finitude, ainda que apareça sob certo ponto de vista como um mero não-ser, acaba sendo recuperada e acolhida no seio do próprio Absoluto nesse jogo de reflexos em que se mostra a identidade entre o finito e o infinito, em que o singular exprime à sua maneira o Absoluto inteiro. É por isso que Schelling pode dizer que, embora conheçamos primeiramente nas coisas a própria essencialidade, "nunca percebemos essa essencialidade para si, mas sempre e em toda parte em uma estranha união [Verein] com o que não poderia ser por si mesmo e é apenas iluminado pelo ser, sem poder tornar-se para si algo de essencial. Nós chamamos isso de finito ou forma" (Schelling, 1857, SW II, p. 360). As coisas singulares não estão separadas do Absoluto porque todas as coisas singulares se compenetram e se unificam em seu centro, isto é, na unidade do Absoluto: o eterno não é nenhuma delas isoladamente e em particular, mas todas e cada uma ao mesmo tempo, de modo que singularidade e totalidade são simultânea e identicamente em sua informação divina. "As afirmações particulares, compreendidas na afirmação infinita, não a precedem, tampouco esta é a composição daquelas, ao contrário, ela é sua absoluta unidade ou seu centro, a posição de todas e de cada uma delas de maneira igual" (Schelling, 1860a, SW VII, p. 160). Essa afirmação infinita de si mesmo por meio de infinitas posições de si mesmo, pensada através do jogo da figuração e da Ineinsbildung, é certamente eterna: como vimos, há uma simultaneidade absoluta entre 
todas as potências e o tempo não deixa de ser pensado como uma marca do finito separado, o qual, considerado tal como ele é no Absoluto, se resolve em sua eternidade. Entretanto, como nota Courtine, "não é menos verdade que este [sc. o jogo] desenvolve progressivamente em efeitos a diversidade de suas figuras" (Courtine, 1990a, p. 131). Assim, o próprio tempo acabará sendo recolhido no Absoluto, suprimindo de certa forma a oposição entre tempo e eternidade, na medida em que tudo o que é só é enquanto autorrevelação do Absoluto e que tal revelação se desdobra historicamente, exigindo algo como uma temporalização do próprio Absoluto ${ }^{10}$.

Sobre esse tema, cf. Courtine, J.-F. 1990b e 1990c.

Não trataremos aqui desse caráter "histórico" do Absoluto, uma vez que ele já extrapola o âmbito da filosofia da identidade e será tratado incessantemente por Schelling a partir do monumental projeto inacabado das Weltalter. Gostaríamos, no entanto, de indicar aqui alguns aspectos do problema do tempo e da história na filosofia de Schelling, partindo do que, na filosofia da identidade, anuncia a filosofia dita "intermediária" e a Spätphilosophie. Essa relação íntima entre tempo e eternidade, pensada a partir da relação entre o finito e o infinito, já aparece no Bruno (Schelling, 1973, p. 261; SW IV, p. 251): "Assim, portanto, nenhum finito é, em si, fora do Absoluto e apenas por si mesmo, singular, pois no Absoluto aquilo que no finito é ideal sem tempo é também real e, se aquela relação de possibilidade é a de causa e efeito, é ele que se põe essa relação e, se isso não ocorre sem o tempo, ele se põe seu tempo, e põe, aliás, aquilo de que põe apenas a efetividade sem a possibilidade como passado e aquilo de que põe a possibilidade sem efetividade como futuro". Da mesma forma, na Filosofia da Arte, também uma certa relação entre tempo e eternidade é posta, por exemplo, na ideia de geração dos deuses em que o processo teogônico aparece como recapitulação da Natureza do ponto de visto mitológico-ideal, cf. Schelling, 2010, p. 68; SW V, p. 405: "por isso, Júpiter é pai dos deuses e dos seres humanos, e mesmo seres que já nasceram são novamente gerados por ele, uma vez que o curso do mundo somente com ele se inicia, e tudo tem de ser nele, para ser no mundo". Em outras palavras, a geração garante ao mesmo tempo a dependência do que é gerado e sua absolutez ou autonomia (dependência em relação ao vir-aser, mas não em relação ao ser), na medida em que consiste em uma gênese que não é ex nihilo, mas repetição da criação divina em que se introduz o curso do mundo e do tempo, ou seja, uma ordenação temporal e cósmica. No entanto, será somente mais tarde que uma temporalização do Absoluto propriamente dita ganhará direito de cidadania na filosofia schellinguiana, quando o problema será pensar o "sistema dos tempos" a partir da ideia de um Deus vivo, isto é, que se revela a si mesmo, saindo da inconsciência e acedendo progressivamente à consciência de si em um processo de autorrevelação em que Bewußtseyn é um Bewußtwerden. E é mais uma vez o problema 
da Absonderung que dará ensejo ao projeto das idades do mundo, visto que o fundamento da efetividade da diferenciação deve estar no próprio Deus. Assim, se a prioridade da primeira potência, em Deus considerado absolutamente, é uma prioridade segundo a ideia, é preciso que Deus ponha essa prioridade ideal como efetiva e se restrinja voluntariamente à primeira potência, suprimindo a simultaneidade originária dos princípios. Mas essa supressão não é supressão da unidade interna nem da ligação entre as potências, pois a posição da primeira implica necessariamente a posição da segunda e da terceira potências. "Se a prioridade da primeira potência se torna uma prioridade efetiva, a identidade das potências no absoluto não é suprimida, ela apenas se metamorfoseia em uma concatenação ou coesão [Verkettung oder Cohärenz] destas. Antes, as potências se encontram nele em completa indiferença ou indistinguibilidade. Da mesma forma, todo o tempo se encontra nele implicite, enquanto unidade ou eternidade". Desde então, essa restrição voluntária de Deus à primeira potência — ou contração total de Deus no real - institui um começo do tempo, ainda que não se trate de uma instituição no tempo: "Por sua restrição à primeira potência, certamente é posta nele de pronto uma limitação [Beschränkung], mas, uma vez que esta contradiz sua essência, visto que ele é segundo sua natureza todas as potências, assim surge um progredir da primeira à segunda e, com isso, um tempo. As potências são agora postas ao mesmo tempo como períodos da auto-revelação de Deus [grifo nosso]". Por conseguinte, o tempo é posto no real (no ser de Deus) sem que isso signifique que o próprio Deus, em sua totalidade, esteja no tempo, de modo que apenas o que nele é singular e restrito pode progredir e desenvolver-se. Se a diferença - e, consequentemente, o tempo - é posta no real, a posição dessa diferença $\left(\mathrm{A}^{2}\right)$ é posta em Deus, no qual está contido simultânea e eternamente tudo o que se desdobra temporalmente no $\mathrm{A}=\mathrm{B}$. Assim, $\mathrm{A}^{2}$ ou Deus como sujeito é a unidade do tempo, ao passo que $\mathrm{A}^{3}$ ou Deus considerado absolutamente "não é eternidade nem tempo, mas identidade absoluta de eternidade e tempo. Tudo o que é no tempo é eterno nele como sujeito e tudo o que é eterno nele como sujeito é temporal nele como objeto" (Schelling, 1860b, SW VII, pp. 428-431). Portanto, contra a tradição metafísica do nunc stans ou que busca conceber uma eternidade "pura" sem nenhuma mistura com conceitos temporais, é preciso pensar uma eternidade viva ou efetiva: "a verdadeira eternidade não é a que exclui todo tempo, mas a que contém e domina o próprio tempo (o tempo eterno). Eternidade efetiva é superação [Ueberwindung] do tempo; [...] Também na vida divina, como em toda outra vida, há movimento, progressão". No entanto, é preciso atentar para a diferença entre a vida divina e qualquer outra vida: em primeiro lugar, na vida em geral, a sucessão e o encadeamento podem dissolver-se, ao passo que eles são indissoluvelmente ligados na vida divina enquanto perpétua elevação. Além disso, em Deus essa sucessão é uma sucessão efetiva que não se desenrola no tempo: "em um único e mesmo ato (no ato da grande decisão), 1 (a primeira potência) é posto como o antecedente de 2,2 como o antecedente de 3 e assim novamente o todo $(1,2,3)$ como o antecedente de 4 , i.e., na própria eternidade 
A reflexão merleau-pontiana sobre a natureza é inteiramente impregnada pelas ideias de Schelling. Assim, Merleau -Ponty se apropria da ideia de erste Natur do ponto de vista da relação que ela estabelece entre o infinito e o finito nos termos da produtividade e do produto - e é essa relação, enfim, que lhe permitirá falar em um Absoluto não-separado. Embora o fenomenólogo se apoie sobretudo nos textos da primeira filosofia da natureza - ou seja, do período que antecede imediatamente a filosofia da identidade —, pareceu-nos interessante focar nossa atenção nesta última, na medida em que, como diz Judith Schlanger, "toda a filosofia da Identidade será a generalização do 'empirismo absoluto' da filosofia da Natureza" e "é nos quadros da filosofia da Natureza que a filosofia da Identidade tratará a problemática do infinito e do finito" (Schlanger, 1966, p. 104), de modo que, trabalhando com a filosofia da identidade enquanto "versão formalizada" da filosofia da natureza, possamos ver uma convergência mais geral entre os dois autores, para além dos conteúdos da filosofia da natureza. Tal convergência se manifesta no fato de que ambos buscarão pensar uma relação expressiva entre o Absoluto e o singular, o

uma sucessão, um tempo são compreendidos; ela não é uma eternidade vazia (abstrata), mas contém em si o próprio tempo superado" (Schelling, 1861, SW VIII, pp. 260-262). Ora, é essa ideia de uma eternidade viva que permite pensar a "genealogia do tempo" ou um "sistema dos tempos": assim como o privilégio do presente levava ao equívoco de pensar a eternidade como nunc stans, também a temporalidade deve ser pensada em sua sistematicidade ou organicidade, como distensão ekstática de passado-presente-futuro, de modo que cada tempo é todo o tempo, isto é, o tempo em sua sistematicidade diferenciada. Não se pode, pois, falar simplesmente "tempo", mas, ao contrário, sempre e necessariamente tempos. O tempo não é, assim, uma forma da sensibilidade, ele é interior às próprias coisas: em cada coisa, o tempo nasce novamente a partir da eternidade. De sorte que, por fim, a temporalidade não é uma sequência mecânica, mas "uma infinidade dinâmica de tempos diferentes, que exprimem, cada um por si, o todo do tempo. O eterno começo dá, literalmente, um tempo a cada coisa. Ele lhe atribui um tempo tal como lhe atribui um lugar" e, portanto, "a genealogia dos tempos nos conduz, assim, a uma visão acabada da história como unidade plural, totalidade orgânica, visão dinâmica em que todos os elementos se imbricam para constituir a lenta elevação da vida à liberdade" (Maesschalk, 1989, pp. 223, 225). 
infinito e o finito, relação que, se pode conservar ainda o nome de dialética, não se deixa reconduzir àquilo que essa palavra designa na tradição hegeliano-marxiana. Ora, pensar uma tal relação expressiva exige, como indicamos ao comentar rapidamente o itinerário de Schelling, conceber algo como uma temporalização do Absoluto, a partir da qual se torna possível pensar um movimento de mão dupla entre o infinito e o finito. Desse modo, para que possamos avaliar corretamente essa convergência, é preciso que nos debrucemos agora sobre a maneira como Merleau-Ponty articula esse problema nos termos de uma Urhistorie a título de uma historicidade do próprio Ser.

Na obra de Merleau-Ponty, a década de 1950 é marcada por um esforço constante de "dessubjetivação" da fenomenologia: todo o problema consiste em pensar a dimensão do sentido como uma dimensão não originariamente constituída pela subjetividade, mas que possui uma produtividade própria, independente dos poderes constituintes do sujeito. Daí o interesse pela erste Natur schellinguiana (ou o "princípio bárbaro"), mas também pelo conceito husserliano de Terra [Erde] e pelas ideias de Whitehead. Com efeito, nos três casos, o que está em questão é uma camada ontológica anterior ao próprio sujeito, que o sustenta e o engloba. Ou seja, Merleau-Ponty não pode mais se contentar com o modelo hegeliano/kojèviano da história como antiphýsis, segundo o qual a natureza seria pura positividade inerte na qual a subjetividade viria introduzir a negatividade e, assim, o movimento e a história ${ }^{11}$. Ao contrário, será preciso encontrar já na natureza certa negatividade, ou seja, reconhecer-lhe uma expressividade e uma produtividade internas que a dimensão propriamente humana recolhe e prolonga em outro sentido, de modo que a cultura não é uma produção ex nihilo que se faz em oposição à natureza — isto é, uma antiphýsis —, mas um prolongamento e uma metamorfose da produtividade natural que permanece nela enraizado e dela se alimenta constantemente. Não é nosso propósito aqui, contudo, reconstituir detalhadamente esse movimento de dessubjetivação da

$11 \quad$ Cf. Merleau-Ponty, 1968, p. 91: "Todo naturalismo posto à parte, uma ontologia que se cala sobre a Natureza se encerra no incorporal e dá, justamente por essa razão, uma imagem fantástica do homem, do espírito e da história”. 
fenomenologia, mas apenas investigar como nele se manifesta uma nova articulação entre o Absoluto e suas "figuras", dando ensejo a uma reformulação das relações entre infinito e finito, eternidade e temporalidade.

Uma primeira elaboração dessa articulação — que será aprofundada pelas investigações sobre a natureza - se encontra no curso inédito de 1955-1956 sobre a filosofia dialética: aqui se formula o quadro "lógico" da ontologia merleau-pontiana, assentando o terreno no qual Merleau-Ponty poderá acolher as contribuições de Schelling, Husserl e Whitehead em direção a uma ontologia do "Ser bruto". Vejamos como isso se dá12.

As três características fundamentais do pensamento dialético residem em que ele é um pensamento de contraditórios, subjetivo e circular. Já uma primeira manifestação da contradição que ele pensa se encontra na coisa: ora, a coisa não é uma identidade a si, mas uma totalidade infinita cuja aparição só se dá à distância, através de seus momentos finitos - e, nesse sentido, a coisa deve ser definida como mediação do infinito e do finito, e não "soma" dos dois. Daí que, para Merleau-Ponty, ela seja antes "algo" que propriamente uma "coisa", isto é, ela é uma Gestalt, um etwas perceptivo que se organiza como figura sobre um fundo, de sorte que não se reduz à res, pretensa realidade positiva, mas é uma configuração sensível. E é nessa configuração própria ao campo perceptivo que uma identidade perceptiva pode realizar-se através de uma multiplicidade, pois sua aparição é estruturada pelo campo ao qual ela reenvia, campo que, por sua vez, se inscreve em um mundo constituído por uma tensão de contraditórios: "se todo ser já é algo, portanto, se ele é uma estrutura do tipo figura-fundo, é porque há, antes de todo ser determinado, o mundo como abertura ao ser, como totalidade em processo, infinidade de seres que se configura em cada ser e que permite a cada ser, ao incorporá-la, cristalizar-se em 'algo"' (Larison, 2016, p. 191). Em outras palavras, o mundo é uma tensão entre unidade e multiplicidade, individualidade e generalidade, absoluto e relativo, positivo e negativo, infinito e finito - em suma, ele é mediação, o que equivale a $12 \quad$ Uma vez que as notas desse curso permanecem inéditas, apoiar-nos-emos no comentário feito por Mariana Larison em Larison, 2016, cap. IV, parte 1. 
dizer que ele é transcendência, ser à distância que, por ser sempre atravessado por sua negação, não pode coincidir consigo mesmo. Mas, ao mesmo tempo, a dialética é um pensamento subjetivo, pois a configuração sensível pressupõe um sujeito $a$ quem ela aparece. Contudo, essa subjetividade não pode ser pura presença a si, mas distância a si, écart: há aqui um "campo de vida" que está aquém da separação entre o imanente e o transcendente, de modo que a subjetividade já é uma generalidade enquanto propriedade de um campo. "Subjetividade, coisa, mundo e outrem formam um sistema cujos momentos não são independentes, mas interdependentes, em que tudo se mantém em conjunto" (Ibid., p. 195). Finalmente, a dialética é um pensamento circular e isso em dois sentidos. Em primeiro lugar, há circularidade entre o movimento dialético e seu começo, isto é, o movimento dialético é movimento da experiência na medida em que ela se volta sobre si como reflexão, de sorte que ele é um pensamento que não coincide consigo mesmo, reflexão sobre um irrefletido. Mas, além disso, há circularidade entre o movimento e sua finalidade, ou seja, a totalidade: cada movimento parcial da experiência se supera em direção à experiência total, mas essa superação é sempre parcial, não nos conduz a um fim do movimento - a totalidade não se fecha sobre si mesma, mas é movimento de totalização. Portanto, se há aqui uma "superação que conserva", um movimento em direção ao futuro que reenvia ao passado, o movimento dialético é fundamentalmente temporal: como diz Merleau-Ponty, "o movimento em direção ao futuro é interiormente animado por apelo do passado. Ele vem do fundo do futuro e do fundo do passado. Ele compreende os dois ao mesmo tempo: eis a situação dialética" (apud Ibid, p. 96). Assim, a totalidade do tempo está implicada em cada momento do movimento dialético, o presente é cristalização de uma temporalidade mais ampla, assim como o "algo" é cristalização do infinito. Por isso, a experiência, enquanto sujeito do movimento, não é nada que se possa determinar fora do próprio movimento e, uma vez que sua superação nunca é total, esse movimento é conservação $e$ criação, história em que passado e futuro se refundam no campo do presente, de sorte que seus momentos não são subsumidos a uma identi- 
dade superior, mas momentos e totalidade se relacionam como o ser perspectivo e o ser à distância. Segundo Merleau-Ponty, o pensamento dialético é o absoluto à distância, e a verdade do círculo dialético pode ser formulada assim: "o ser à distância através da perspectiva $=$ parcialidade, mas o ser $=$ totalização, totalização que se faz justamente por minha inserção do [sic] ser e, portanto, por minha parcialidade" (apud Ibid., p. 197). Desde então, não nos instalamos no particular nem no universal puros, pois o particular já é abertura à totalidade, ao universal que permanece sempre à distância, em filigrana através do particular, de modo que não há exterioridade entre um e outro, mas eles se imbricam e, em certa medida, são o mesmo.

Essa caracterização sumária e um pouco esquemática da dialética merleau-pontiana já nos permite ver que o que está em jogo aqui é uma compreensão do Ser como mediação em ato ou nexus, na medida em que a dialética é a estruturação da experiência do Ser enquanto Ser sensível e, portanto, atravessado por uma profundidade, negatividade operante que o impede de ser pura coincidência e positividade. Daí que o ente tampouco seja um ob-jeto, mas um etwas perceptivo, figura que se diferencia de um fundo ao qual reenvia - e é aqui, pois, que poderemos reencontrar a dialética em obra na natureza, dialética que foi recalcada pela tradição cartesiana, mas que Merleau-Ponty verá ressurgir na filosofia de Schelling justamente quando ele afirma um Absoluto não-separado, "Abismo" enquanto horizonte infinito dado em filigrana, como invisível, em toda intuição do finito, o que só foi possível porque, segundo Merleau-Ponty, a filosofia schellinguiana não é uma filosofia do objeto, mas do tempo. Assim, o que está em jogo é uma produtividade do Absoluto que só existe à distância, através de suas produções finitas:

A circularidade dialética permite entrever que todo começo tem um passado, que ele é o resultado de um movimento maior, movimento de um Si ou Sujeito Absoluto que é a totalidade totalizante da experiência na qual os momentos parciais se inscrevem. A circularidade dialética implica, pois, uma relação de duplo sentido do todo com as partes e das partes com o todo, o que conduz a uma concepção da experiência e da História na qual o movimento de conjunto pode ser concebido como povoado de significações parciais e opostas sem 
que haja necessidade de subordinar definitivamente o movimento a elas. Em suma, essa circularidade permite pensar um Absoluto ou Totalidade que transcende as produções finitas mas que só existe em filigrana através delas (Ibid., p. 227).

É, pois, sob esse prisma que poderemos compreender corretamente os passos que levam Merleau-Ponty à ontologia do Ser bruto.

Uma primeira face desse Absoluto produtivo aparece, por exemplo, na análise que Merleau-Ponty empreende do conceito husserliano de Terra. Em oposição à doutrina copernicana, Husserl dirá que a Terra não é um corpo entre outros, mas, ao contrário, um solo de experiência unicamente sobre o qual pode haver corpos. E, se ela não é um objeto entre outros, mas a fonte a partir da qual eles são engendrados, então não é possível aplicar-lhe as categorias intramundanas: ela não é infinita nem finita, não é móvel nem em repouso, não é espacial nem temporal, ela está aquém dessas determinações. Desde então, não cabe à filosofia voltar-se para o alto, isto é, para as ideias: ela deve, ao invés, converter-se em uma arqueologia desse "solo", investigar sua profundidade. Com efeito, é somente por meio desse movimento arqueológico que se tornará possível compreender o modo de ser dos "objetos" ou corpos que estão sobre tal solo - e, mais que isso, a investigação mostrará esse solo originário como a raiz de toda história, na medida em que ele é a condição de surgimento de todo sentido. A Terra, diz Merleau-Ponty, "é um tipo de ser que contém todas as possibilidades ulteriores e lhes serve de berço" (Merleau-Ponty, 1995, p. 110). Daí que Husserl a caracterize como "arca originária", pois "assim como a arca de Noé comportava tudo o que podia restar de vivo e possível, da mesma forma a Terra pode ser considerada como portadora de todo o possível" (Ibid., p. 111), ou seja, ela é o real do qual todos os possíveis provêm a título de seus variantes, possíveis que estão contidos nela como horizontes. Assim, se a Terra está aquém da partição entre infinito e finito, é porque ela não consiste em uma infinitude concebida como Unendlichkeit - que se reduziria a uma somatória de realidades finitas, caracterizando-se como infinito positivo mas como Offenheit, infinito negativo ou de profundidade no 
qual o possível aparece como modalidade da presença, isto é, em seu caráter de horizonte [Horizonthaftigkeit]. Essa oposição entre o infinito como Offenheit e como Unendlichkeit vai de par com a crítica à ontologia moderna enquanto ontologia positiva, incapaz de pensar a negatividade inerente ao Ser - e aqui, além de Descartes e seus sucessores, o alvo imediato é a ontologia sartreana do Em si e do Para si. Pois, se o sentido só pode ser pensado como desvio [écart], ele exige que o Nada deixe de ser concebido como nichtiges Nichts e seja incorporado ao Ser.

Para compreender essa infinitude de abertura que define a Terra, pelo menos tal como Merleau-Ponty a entende, é preciso fazer um pequeno desvio. Em diversas passagens, Merleau-Ponty aproxima a Offenheit husserliana da ideia heideggeriana de Verborgenheit-Unverborgenheit, aproximação que é inseparável da elucidação de seu par conceitual visível-invisível. Assim, o invisível não é somente um invisível de fato, um "outro visível" definido como um positivo simplesmente ausente: ao contrário, diz o fenomenólogo, "ele é Verborgenheit de princípio, i.e. invisível do visível", para acrescentar logo em seguida: "Offenheit de Umwelt e não Unendlichkeit" (Merleau -Ponty, 1979, p. 300, maio de 1960) ${ }^{13}$. Tal aproximação deve ser entendida no interior do esforço mais geral de dessubjetivação da fenomenologia: com efeito, o que Merleau-Ponty absorve do segundo Heidegger é uma abertura que não se faz mais "subjetivamente", isto é, a partir do Dasein, mas a partir do próprio Ser, pois o Dasein "só é Dasein por sua abertura ao Ser, em um funcionamento ontológico do qual ele é apenas o 'lugar' e que passa ao primeiro plano", ou seja, "o Dasein se torna um movimento do Ser que atravessa o homem, que 'o possui'" (Merleau-Ponty, 1996, pp. 98, 99), na medida em que o " $D a$ " aparece como Offenheit des Offenen. Essa "abertura do aberto" está relacionada ao sentido da verdade enquanto verdade do Ser - e que, portanto, não se reduz à concepção clássica de verdade como adequação, uma vez que esta pressupõe a verdade do Ser, pois, para que haja adequação, é preciso que haja uma pré-abertura ao Ser, ou seja, um aberto no interior do qual

$13 \quad$ No caso das notas de trabalho publicadas anexas a Le visible et l'invisible, indicaremos, após a página, a data da nota. 
a relação de adequação pode aplicar-se. Mas isso não significa que a verdade seja uma relação exterior em que o homem seria pura e simplesmente passivo, mas somente que ela implica uma relação de transcendência: a verdade não é "dada", ela é não oculta [Unverborgene], á $\lambda \hat{\theta} \theta \varepsilon ı$. O que, por sua vez, tampouco significa uma "evidência", pois a Offenheit é justamente o que instaura uma distância que permite que o ente se revele e, nesse sentido, "subentende um além do que nós vemos, um Ser, i.e., uma Verborgenheit no desvelamento" (Ibid., p. 99). Em suma, o "dom" do Ser, sua eclosão, é também e indissociavelmente um "retirar-se" [Sichentziehen], o desvelamento de um ente particular é velamento do Ser do ente, o qual se mantém à distância enquanto o invisível que torna possível a visibilidade do ente, invisível que, enquanto jamais desvelado, permanece da ordem do mistério. Mas Merleau-Ponty se apressa em recusar a acusação habitualmente feita contra Heidegger de "misticismo". O Ser não é um ser em si — o que redundaria, é claro, em uma entificação do Ser - ao qual a Verborgenheit viria se acrescentar como propriedade segunda e que seria, em si ou para si, manifesto. Dizer do Ser que ele é oculto significa dizer que ele é essa dupla relação de velamento e desvelamento, que o desvelamento total é uma ilusão e que, portanto, toda verdade (entendida como á- $\lambda \hat{n} \theta \varepsilon \imath a)$ é igualmente - e de modo mais fundamental - uma não-verdade, Unwahrheit. Assim, Merleau-Ponty vai dizer que as fórmulas pretensamente místicas de Heidegger são, na verdade, fenomenológicas, o que mostra a identidade entre fenomenologia e ontologia: "na verdade, retirar-se significa: o ser se oculta como ser fazendo-se ente" e "dizer que o Ser é oculto, [é] a ideia de que o que vem zum Vorschein é por princípio da ordem do ente e inadequado ao Sein" (Ibid., p. 119). Dito de outro modo, o visível só existe sobre um fundo de invisível de direito, o Ser só se manifesta (só se faz ente) ocultando-se como Ser desse ente. Como diz Franck Robert, "o invisível é o Ser cujo sentido é o nada de sua própria articulação, ou seja, o próprio invisível de toda articulação" (Robert, 2005, p. 264).

Agora, podemos retornar ao problema de que partimos. A partir de nosso excurso heideggeriano, a infinitude da Terra 
pode, então, definir-se como excesso do Ser sobre suas manifestações finitas, isto é, como fundo primordial e inesgotável que se fenomenaliza em figuras, o horizonte que aparece se retirando e que sustenta toda abertura. "O mundo, diz Merleau-Ponty citando Husserl, é constituído in einer Horizonthaftigkeit, in welcher das Seiende als wirklich in allzeit vorgezeichneten Seinsmöglichkeiten konstituiert ist" (Merleau-Ponty, 1998, p. 91) ${ }^{14}$. Se a Terra é o real do qual os possíveis são os variantes, é porque todos os possíveis estão nela prefigurados [vorgezeichnet] enquanto o Ser bruto é polimorfo, o mesmo que se manifesta de infinitos modos como o mesmo. E, como vimos, o Ser não é um ser em si, ele é atravessado por uma negatividade pela qual ele se manifesta e se faz mundo, de sorte que sua manifestação não lhe é acessória, mas, ao contrário, o sentido de ser do Ser não é nada além de aparecer. Daí que para o próprio Heidegger o Ser deva ser pensado como púoıs, eclosão, na medida em que é uma autoprodução contínua - o que permite a Merleau-Ponty estabelecer uma equivalência entre Terra e Natureza tal como ele a lê, por exemplo, em Schelling. "A natureza é ao mesmo tempo passiva e ativa, produto e produtividade, mas uma produtividade que sempre precisa produzir outra coisa" (Merleau-Ponty, 1995, p. 61), ou seja, produtividade interminável que é unidade entre infinito e finito: "o Absoluto não é somente o Absoluto, mas o movimento dialético do finito e do infinito. O Absoluto é de tal forma que ele nunca aparece senão a um outro. Assim como nossa intuição é um ek-stase, pela qual tentamos nos situar no Absoluto, o Absoluto deve sair de si mesmo e fazer-se Mundo" (Ibid., p. 73) ${ }^{15}$. Se o Ser se faz ente, ou seja, aparece ocultando-se como excesso sobre o que aparece, agora a infinitude de Offenheit da Terra revela todo seu sentido conforme a dialética entre o infinito e o finito - se${ }_{14} \quad$ Citado em alemão no texto. Tradução nossa: "em um caráter de horizonte no qual o ente é constituído como efetivo em possibilidades de ser sempre prefiguradas".

15 Cf. também Merleau-Ponty, 1996, p. 107: "Este Sein (que não é extensão infinita e compreensão nula, que é ao contrário compreensão aumentando com a extensão, porque ele é o que faz com que uma coisa seja e seja outra que uma outra) [é] o Wesen ativo ou verbal, o que faz com que o mundo weltet e que a coisa dingt, i.e., o ser antes do ser-pensado [...], o ser ativo que west, que 'se desdobra', por oposição ao ser-sido". 
gundo a qual o próprio infinito se finitiza a fim de aparecer e o finito é abertura ao infinito como seu horizonte inesgotável que Merleau-Ponty destaca na natureza schellinguiana. Mundo e Ser se relacionam como o visível e o invisível e é por isso que, diz Merleau-Ponty, "eu sou contra a finitude no sentido empírico, existência de fato que tem limites e é por isso que sou a favor da metafísica. Mas ela não está mais no infinito que na finitude de fato" (Merleau-Ponty, 1979, p. 300, maio de 1960) ${ }^{16}$.

Como vimos, as categorias intramundanas não podem ser aplicadas à Terra, porquanto ela é fonte ou matriz e não está ipso facto na ordem dos entes. Ora, se é assim, tampouco se pode dizer que ela esteja no espaço e no tempo, de modo que ela deve revelar-se igualmente como matriz do espaço e do tempo. Assim, diz Merleau-Ponty, se se pode falar em um Erdraum na medida em que os corpos se movem na superfície da Terra e dela se destacam, é preciso levar em conta que esse "espaço" está aquém de toda localização espacial, localização que só pode emergir a partir desse "espaço": nas palavras de Husserl citadas por Merleau-Ponty, "einen umgebenden Raum haben wir als Ortsystem - d.i. als System möglicher Enden von Körperbewegungen. Aber darin haben wohl alle irdischen Körper, aber nicht die Erde selbst eine jeweilige 'Stelle"' (apud Merleau-Ponty, 1998, p. 85) ${ }^{17}$. Enquanto um tal sistema, a Terra é um ser pré -espacial que funda a aparição no espaço, ou seja, o domínio propriamente ôntico com suas "localidades". Da mesma forma, ela está aquém de toda determinação temporal: "o sensível, a Natureza, transcendem a distinção passado presente, realizam uma passagem pelo interior de um no outro. Eternidade existencial. O indestrutível, o Princípio bárbaro" (Merleau-Ponty, 1979, p. 315, novembro de 1960). A ideia de uma "eternidade

16 Cf. também uma nota de trabalho inédita apud Robert, 2005, p. 268: "Distinguir o 'mundo' no sentido empírico-ôntico (i.e., como fato empírico sobre fundo de outros possíveis, e da ontologia do ens realissimum distinto desse fato) e o 'mundo' no sentido ontológico ou Ser, i.e., como única apresentação possível do Ser distante, oculto".

17 Citado em alemão no texto. Tradução nossa: "temos um espaço circundante como sistema de localização - i.e., como sistema de fins possíveis dos movimentos dos corpos. Mas nesse sistema todos os corpos terrestres têm o seu respectivo 'lugar', mas não a própria Terra". 
existencial" - que Merleau-Ponty equaciona ao "passado indestrutível" e ao "princípio bárbaro" schellinguiano — indica um movimento de temporalização interior ao Ser, no qual se torna possível conceber o passado enquanto passado, ou seja, não como um presente que passou - o único passado que a analítica intencional é capaz de pensar - , mas como um passado originário que é Simultaneidade entre passado e presente, "passado vertical" que dá o verdadeiro sentido do presente como "presente dimensional", isto é, mundo. Essa temporalização do Ser é aquilo que Whitehead chamava de passagem da natureza, a natureza como desdobramento espaço-temporal e "memória do mundo", temporalização originária que engendra os entes como durações particulares: "uma duração é duração porque ela conserva algo da passagem da Natureza, porque ela é execução desse processo" (Merleau-Ponty, 1995, p. 164).

O Ser bruto deverá, pois, caracterizar-se ao mesmo tempo por uma espacialização e por uma temporalização originárias, que é o que Merleau-Ponty chama de turbilhão espacializante-temporalizante. O retorno ao Ser bruto, diz o fenomenólogo, implica "retornar ao tempo, ao espaço brutos, selvagens, antepredicativos, 'amorfos', como à matriz da qual derivam os tempos cíclicos, seriais etc." (apud Ferraz, 2009, p. 322), de sorte que o tempo originário, isto é, a auto-temporalização do Ser, deverá ser pensado como ontogênese. Mais que isso, o que a ideia de turbilhão permite pensar é uma indissociabilidade entre tempo e espaço enquanto ambos passam um no outro enquanto articulação fundamental do mundo, estruturas invisíveis que sustentam a visibilidade do visível. Por isso, "todo acontecimento é do tipo do acontecimento histórico de que fala Péguy 'ritmo do acontecimento do mundo"' (Merleau-Ponty, 1979, p. 246, 20 de maio de 1959). Daí que Merleau-Ponty possa retomar — ainda que em um sentido diferente - a ideia heideggeriana de Seinsgeschichte: se o tempo originário é "gemulação" do Ser,

seria melhor dizer, em vez de 'tempo', que evoca uma 'forma', 'história', que evoca [uma] operação do ser. E para evitar [a] confusão com [a] noção correlativa dos conteúdos do tempo ('história' no 
sentido de série dos atos e das paixões do homem - História ${ }^{18}$ ), será preciso dizer Geschichte, ou melhor, Seinsgeschichte: i.e. o que advém não como innerzeitig, intra-temporal, individuado espaçotemporalmente, mas enquanto elemento de uma gemulação [bourgeonnement] do ser, enquanto advento, enquanto dado em partilha ao Dasein e ao Mit-dasein, enquanto Moĩpa ou Geschick,

história do Ser que deverá ser pensada simplesmente como o movimento pelo qual das Sein west, manifesta-se ocultando-se, produz um mundo, de modo que ela é uma "nova ocasião de perceber a operação metafísica do Ser, seu retirarse fecundo, esses dons que ele faz e que não o diminuem, que antes o aumentam - operação que é a verdade das 'representações' metafísicas do infinito" (Merleau-Ponty, 1996, pp. 136, 137). Em suma, o que a história do Ser, a partir da ideia de tempo e espaço brutos, designa não é outra coisa que a unidade entre produtividade e produto, infinito e finito, eternidade e temporalidade, uma única eclosão eterna pela qual o Ser se autodiferencia e se manifesta.

No entanto, se a contribuição de Heidegger é fundamental, resta que o Ser merleau-pontiano não é exatamente igual ao Ser heideggeriano, sobretudo porque o Ser, para Merleau-Ponty, é sensível. É que a "operação metafísica do Ser", o fato de que o Ser é Wesen ativo ou verbal, significa uma operação de Gestaltung, o Ser polimorfo se exprime produzindo Gestalten, ou seja, uma configuração sensivel - cuja estruturação define o conceito merleau-pontiano de dialética, como vimos. "Portanto, a Gestalt implica a relação de um corpo percipiente com um mundo sensível, i.e. transcendente i.e. de horizonte i.e. vertical, e não perspectivo. É um sistema diacrítico, opositivo, relativo cujo pivô é o Etwas, a coisa, o mundo, e não a ideia" (Merleau-Ponty, 1979, p. 256, setembro de 1959). Daí que todo ente deva aparecer como figura sobre um fundo como mediação por si de finito e infinito - isto é, que a figura surja destacando-se de um fundo que a excede infinitamente. Quando Merleau-Ponty retoma a ideia heideggeriana de que o

18 Trata-se, provavelmente, de um erro de transcrição, pois o que faria mais sentido aqui seria o termo alemão Historie, que Merleau-Ponty, na esteira de Heidegger, opõe a Geschichte. 
Dasein se torna um movimento do Ser que atravessa o homem, movimento que é precisamente a Offenheit, ele vai entender essa ideia conforme a inflexão que o caráter sensível do Ser lhe impõe: dizer que o corpo é carne não é fazer dele o princípio da abertura, mas nomear essa estruturação sensível da experiência - graças à qual pode haver um "sujeito" e um "objeto", as aspas designando a relatividade dessas funções enquanto só existem por sua distribuição no interior do campo - que é estruturação do Ser no duplo sentido do genitivo ${ }^{19}$. Há, portanto, um movimento do próprio Ser enquanto Ser sensível que é uma história, história das infinitas figuras que, prefiguradas pelo fundo primordial, vêm à manifestação na medida em que são retomadas e desdobradas pela história propriamente humana. A produtividade infinita do Ser só pode se manifestar cristalizando-se em produtos finitos, nos quais justamente ela se manifesta como excesso. E, como vimos, esse movimento é o próprio Ser, uma vez que nele há identidade entre sair de si e voltar a si, ele é Ser sensível, figura e fundo indissociavelmente. Isso permite que a criação humana tenha um lugar, embora ela não possa ser pensada como ex nihilo, mas como algo que recolhe um sentido latente nesse fundo e faz com que ele passe ao estado de figura:

o mundo perceptivo 'amorfo' do qual eu falava a propósito da pintura - recurso perpétuo para refazer a pintura —, que não contém nenhum modo de expressão e que, no entanto, chama e exige todos eles e res-suscita com cada pintor um novo esforço de expressão esse mundo perceptivo é, no fundo, o Ser no sentido de Heidegger, que é mais que toda pintura, que toda fala, que toda 'atitude' e que, apreendido pela filosofia em sua universalidade, aparece como contendo tudo o que jamais será dito e deixando-nos, no entanto, a criá

\footnotetext{
19 Cf. Larison, 2016, pp. 295-6: "Portanto, é um ser sempre estruturado, que reenvia de si para além de si, em direção a uma totalidade mais ampla e mais aberta que é a do campo fenomenal. Mas ele também reenvia diretamente ao sujeito percipiente, àquele a quem o fenômeno se doa. Ele reenvia, por isso, ao que Merleau-Ponty chama de carne, noção difícil na qual se inscreve a dupla dimensão do sujeito: ao mesmo tempo sujeito de um campo perceptivo-vital (a carne do corpo) e sujeito do movimento da experiência (a estrutura ou forma subjetiva do mundo, o mundo no sentido do "mundo da vida', da cultura e da história, enfim, a 'carne do mundo')".
} 


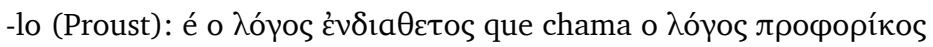
(Merleau-Ponty, 1979, pp. 221-2, janeiro de 1959).

Tanto em Schelling quanto em Merleau-Ponty, encontramos um mesmo esforço teórico de pensar uma vida do Absoluto a partir da qual as dicotomias do pensamento moderno são suprimidas enquanto dicotomias, recebendo uma articulação dinâmica em seu interior. Desse modo, a unidade do Absoluto não somente não exclui a diferenciação, como também a exige - o que põe em xeque desde já a célebre crítica de Hegel, no prefácio da Fenomenologia do Espírito, ao Absoluto schellinguiano como noite em que todos os gatos são pardos. Vimos que a forma do ser da identidade absoluta implica a finitude, que ela só pode ser posta como efetiva na medida em que põe a diferença entre sujeito e objeto, em que o $\mathrm{A}=\mathrm{A}$ se transforma em $\mathrm{A}=\mathrm{B}-\mathrm{e}$, mais que isso, Schelling dirá que o ser originário ou o Deus vivo só pode ser a identidade da identidade e da diferença, de $\mathrm{A}=\mathrm{A}$ e de $\mathrm{A}=\mathrm{B}$. De maneira análoga, vimos que Merleau-Ponty, em sua leitura cruzada de Husserl e Heidegger, tenta pensar o Ser como movimento de autodiferenciação, estabelecendo uma identidade entre ser e manifestar-se que garante ao mesmo tempo a unicidade do Ser e sua proliferação em infinitas figuras. Nos dois casos, não há mais nenhuma exterioridade entre infinito e finito, uma vez que este é expressão daquele: essa dialética expressiva é o que definirá, para Merleau-Ponty, o finito como mediação por si ou cristalização do infinito, figura em que o fundo infinito se desvela e se vela simultaneamente enquanto excesso; para Schelling, é o que devolverá uma dignidade ao finito - que havia sido reduzido pela reflexão, enquanto um ponto de vista que considera o finito como separado do todo, ao estatuto de "puro nada" enquanto forma determinada do ser da identidade absoluta, forma na qual esta pode revelar-se no jogo da Ineinsbildung de essência e forma. Assim, o infinito não pode existir separadamente do finito, o Absoluto exige sua própria manifestação finita para ser posto como efetivo - e, na fórmula das Weltal- 
ter, para aceder à consciência de si - já que o puro $\mathrm{A}=\mathrm{A}$, diz Schelling, é o estado do ser "abismado em si" (Deus em sua pura inconsciência), exigindo, pois, a posição do $\mathrm{A}=\mathrm{B}$.

Ora, esse esforço de conceber a unidade entre infinito e finito, Absoluto e singular, não pode prescindir de uma temporalização do próprio Absoluto, temporalização que equivale ao estabelecimento de uma certa história - daí o motivo do "Deus em devir", que ganhará força na obra de Schelling a partir de sua filosofia "intermediária" ${ }^{20}$. Daí também o comentário sucinto, porém preciso, de Merleau-Ponty sobre o Absoluto não-separado não poder ser pensado em uma filosofia do objeto, mas somente em uma filosofia do tempo. Com efeito, se se estabelece a unidade entre produtividade e produto, na medida em que o produto é uma expressão do Absoluto enquanto produtividade - mais uma vez, no duplo sentido do genitivo - , então essa diversidade de produtos ou manifestações deverão formar uma história: história da revelação de Deus e da elevação da vida à liberdade, no caso de Schelling, e história originária em que o Ser, como autodiferenciação e eclosão perpétua, se exprime no jogo entre velamento e desvelamento, no caso de Merleau-Ponty. No entanto, essa história - por seu caráter originário e, digamos, ontológico - exige uma articulação entre tempo e eternidade, pois não estamos mais em regime de separação. Se Schelling afirma a absoluta eternidade da identidade absoluta, nós indicamos que, posteriormente, essa eternidade deverá ser pensada como uma eternidade viva, ou seja, que comporta o tempo "superado" e, por conseguinte, sua tripartição ekstática entre passado-presente-futuro: se o tempo é posto na diferença (existência), em $\mathrm{A}=\mathrm{B}$, a posição (eterna) dessa posição, Deus como sujeito ou existente $\left(\mathrm{A}^{2}\right)$, é a unidade desse tempo, assim como Deus considerado absolutamente $\left(\mathrm{A}^{3}\right)$, ou seja, na identidade $\mathrm{A}^{2}=(\mathrm{A}=\mathrm{B})$, é precisamente a identidade absoluta entre tempo e eternidade. Donde, pois, o tempo só poder ser

20 Cf. e. g. Schelling, 1860b, SW VII, p. 432: "Deus faz a si mesmo e, assim como é certo que ele faz a si mesmo, é igualmente certo que ele não é algo pronto e subsistente desde o início; pois, nesse caso, ele não precisaria fazer-se". O que, no caso de Merleau-Ponty, poderia ser formulado nos termos da negatividade inerente ao Ser, pela qual ele não pode coincidir consigo mesmo em uma positividade inerte, mas é necessariamente inacabado e "movente". 
pensado no interior de um sistema dos tempos, dado que cada coisa recebe seu tempo da eternidade e, a esse título, é idêntico à totalidade do tempo. Merleau-Ponty, por sua vez, vai falar em uma "eternidade existencial" — o que equivale a dizer: eternidade temporal —, o que dá conta de pensar, por exemplo, uma natureza que é sempre a mesma e sempre nova. O Ser é eterna explosão, movimento perpétuo de diferenciação e, nesse sentido, matriz do espaço e do tempo: há, como vimos, um tempo bruto - temporalização originária do Ser - no qual se originam e se unificam em certa medida todas as diferentes estruturações temporais (como o tempo serial e o cíclico), na medida em que essas estruturações são interpretações particulares de um mesmo Ser, diferenciações e expressões de um único Ser.

É claro, em que pese tudo o que dissemos até agora, Merleau-Ponty não é Schelling. Todo nosso esforço de aproximação dos dois autores desabaria no nada se não déssemos a ver também o que diferencia um do outro. Além da diversidade lexical, que já indica aspectos das diferenças de "quadros filosóficos" em que cada um se insere, alguns pontos são mais evidentes. Poderíamos dizer que Schelling e Merleau-Ponty percorrem caminhos inversos: o primeiro parte do infinito e da eternidade e depara com o enigma da finitude, do ser particular que existe no tempo, ao passo que o segundo parte do fático e depara com o mistério da eternidade e do infinito. Grosso modo, o Absoluto é para Schelling um ponto de partida e para Merleau-Ponty um ponto de chegada ${ }^{21}$. Além disso, ainda que ambos cheguem a pensar em uma "história do Absoluto", o caráter dessa história é substancialmente distinto, uma vez que, em Merleau-Ponty, a história originária não possui a dimensão "teofânica" e "escatológica" que ela tem em Schelling. Assim, mesmo se quisermos aproximar as duas ideias de história, é preciso no mínimo fazer a ressalva de que Merleau-Ponty a pensa de uma maneira "laica", por assim dizer. O que significa, por sua vez, que a Seinsgeschichte merleau-pontiana difere inclusive de sua matriz heideggeriana, pois não há aqui nenhuma destinação — ou, de

$21 \quad$ Daí a célebre ideia da impossibilidade de uma ontologia direta e da consequente necessidade de uma ontologia indireta, isto é, de pensar o Ser através dos entes, na própria diferença ontológica. 
modo mais geral, teleologia — ou "historialidade" do Ser e isso mesmo se Merleau-Ponty retoma também o conceito de Geschick ou Moĩ $\mathrm{a}^{22}$. Como vimos, para Merleau-Ponty não há senão superações parciais, porque a totalidade é sempre movimento de totalização: assim, há uma unicidade da história na medida em que ela deve ser reconduzida à história de um mesmo Ser, mas essa história é produção de significações disparatadas, uma produtividade "cega", que, embora seja sempre história do sentido, não postula um fim do movimento em uma totalidade fechada, mas produz campos, núcleos de sentido, matrizes simbólicas, sempre afetados por um coeficiente de facticidade. Por fim, se tanto Schelling quanto Merleau-Ponty pensam essa história a partir de certa figuração do Ser, essa figuração possui sentidos distintos em cada um dos autores, uma vez que Merleau-Ponty a levará ao limite, reconhecendo o Ser como Ser sensível, ao passo que esse caráter fundamentalmente sensível do Ser, até onde saibamos, não tem lugar na filosofia schellinguiana, mesmo se levarmos em conta a identidade fundamental entre real e ideal, que exige sempre algo como uma "encarnação" do ideal.

Levando em conta essa "comunidade" que surge a partir de caminhos inversos e se faz através de diversas diferenças, não seria absurdo dizer que a tentativa dos dois autores de pensar essa unidade mostra um problema mais geral, do ponto de vista da história da filosofia, que é o de se manter em somente um dos termos das dicotomias filosóficas ou, de modo ainda mais geral, de manter essas dicotomias enquanto tais. A própria manutenção dessas dicotomias no pensamento moderno dependia, como diz Merleau-Ponty, da mediação de um infinito positivo ou infinitamente infinito graças ao qual podia haver um "acordo" entre os dois termos da oposição. Com a ruptura desse acordo, cada um dos termos passa a ser pensado como

$22 \quad$ Cf. Robert, 2005, p. 342: "Portanto, o sentido do Geschick para Merleau-Ponty deve ser procurado menos em Heidegger que em Husserl, na compreensão de uma temporalidade pensada a partir da ideia de Stiftung, uma temporalidade própria à Stiftung. [...] Assim, o que Merleau-Ponty busca pensar no fim de sua vida é essa não-dissociação das dimensões ao mesmo tempo histórica e sensível do Ser, não-dissociação que se pensa como história e geografia transcendentais, isto é, finalmente, como geologia e arqueologia transcendentais". 
um absoluto e absorve o outro em si. Mas essa absorção nunca é total, de modo que a dicotomia como pura antítese comporta um ineludível "retorno do recalcado". Desde então, se Merleau-Ponty via em Schelling menos uma "filosofia" no sentido de uma doutrina acabada do que uma experiência do pensamento, é precisamente na medida em que a própria filosofia de Merleau-Ponty é também uma experiência do pensamento que eles podem se aproximar na tentativa de pensar a unidade que subjaz às dicotomias do entendimento, uma vez que essa unidade é o próprio Ser, Ser que, como vimos, é da ordem do mistério. Portanto, além de certos temas e desenvolvimentos comuns, Merleau-Ponty e Schelling se reencontram em uma proximidade mais profunda que é a meditação sobre esse Ser indiviso que nos envolve, nesse retorno, como queria Claudel, a $\Sigma$ í $\eta$ como abismo, o que faz de suas filosofias filosofias inacabadas - não por circunstâncias biográficas, mas essencialmente inacabadas.

\section{Referências}

COURTINE, J.-F. De l'Universio à l'Universitas: le déploiement de l'unité. In Extase de la raison. Essais sur Schelling. Paris: Galilée, $1990 \mathrm{a}$

COURTINE, J.-F. Du Dieu en devenir à l'être à venir. In Extase de la raison. Essais sur Schelling. Paris: Galilée, 1990b

COURTINE, J.-F. Histoire supérieure et système des temps. In Extase de la raison. Essais sur Schelling. Paris: Galilée, 1990c

FERRAZ, M. S. A. Fenomenologia e ontologia em Merleau-Ponty. Campinas: Papirus, 2009

LARISON, M. L'Être en forme. Dialectique et phénoménologie dans la dernière philosophie de Merleau-Ponty. Milão/Paris: Mimesis, 2016

MAESSCHALK, M. Philosophie et révélation dans l'itinéraire de Schelling. Leuven/Paris: Peeters/Vrin, 1989

MERLEAU-PONTY, M. La nature. Notes de cours du Collège de France. Paris: Seuil, 1995

MERLEAU-PONTY, M. Le visible et l'invisible. Paris: Gallimard, 1979 MERLEAU-PONTY, M. Notes de cours (1959-1961). Paris: Gallimard, 1996

MERLEAU-PONTY, M. Notes de cours sur l'Origine de la géometrie de Husserl. Paris: PUF, 1998 
MERLEAU-PONTY, M. Résumés de cours (1952-1960). Paris: Gallimard, 1968

MOISO, F. Una ragione all'altezza della natura. La convergenza fra Schelling e Merleau-Ponty. Chiasmi International 1. Pubblicazione della Società di studi su Maurice Merleau-Ponty. Milão: Mimesis, 1998

ROBERT, F. Phénoménologie et ontologie. Merleau-Ponty lecteur de Husserl et Heidegger. Paris: L'Harmattan, 2005

SCHELLING, F. W. J. Aphorismen zur Einleitung in die Naturphilosophie. In Sämtliche Werke, VII. Stuttgart/Augsburg: J. G. Cotta'scher Verlag, 1860a

SCHELLING, F. W. J. Bruno ou Do princípio divino e natural das coisas: um diálogo. In FICHTE, J. G.; SCHELLING, F. W. J. Escritos filosóficos. Ed. e trad. Rubens Rodrigues Torres Filho. Os Pensadores. São Paulo: Abril Cultural, 1973

SCHELLING, F. W. J. Darstellung meines Systems der Philosophie. In Sämtliche Werke, IV. Stuttgart/Augsburg, 1859a

SCHELLING, F. W. J. Die Weltalter. Erstes Buch (aus dem handschriftlichen Nachla $\beta$ ). In Sämtliche Werke, VIII. Stuttgart/Augsburg: J. G. Cotta'scher Verlag, 1861

SCHELLING, F. W. J. Fernere Darstellungen aus dem System der Philosophie. In Sämtliche Werke, IV. Stuttgart/Augsburg: J. G. Cotta'scher Verlag, 1859b

SCHELLING, F. W. J. Filosofia da Arte. Trad. Márcio Suzuki. São Paulo: Edusp, 2010

SCHELLING, F. W. J. Stuttgarter Privatvorlesungen (aus dem handschriftlichen Nachlaß). In Sämtliche Werke, VII. Stuttgart/Augsburg: J. G. Cotta'scher Verlag, 1860b

SCHELLING, F. W. J. System der gesamten Philosophie und der Naturphilosophie insbesondere. In Sämtliche Werke, VI. Stuttgart/Augsburg: J. G. Cotta'scher Verlag, 1860c

SCHELLING, F. W. J. Ueber das Verhältniß des Realen und des Idealen in der Natur. Oder Entwicklung der Grundsätzen der Naturphilosophie an den Principien der Schweren und des Lichts. In Sämtliche Werke, II. Stuttgart/Augsburg: J. G. Cotta'scher Verlag, 1857

SCHLANGER, J. Schelling et la réalité finie. Paris: PUF, 1966 